\title{
Extractive waste from hard coal mining in Poland - balance, status of management and environmental aspects
}

\author{
Justyna Pyssa ${ }^{1, *}$ \\ ${ }^{1}$ AGH University of Science and Technology, Al. Mickiewicza 30, 30-059 Krakow, Poland, Faculty \\ of Energy and Fuels
}

\begin{abstract}
Extractive waste is produced at all stages of mining activities during preparatory and operational works as well as in processes of mechanical processing of coal. In a significant part it comprises a fullvalue commercial product or a material for the land reclamation. Because of considerable amounts of waste generated by the coal extractive and processing industry, legal, technical, ecological and social aspects related to the possibilities of management of stored materials have been analyzed in the article.
\end{abstract}

\section{Introduction}

Hard coal mining is one of the biggest waste-generating industry branches in Poland. Waste is produced first of all during the coal extraction and its processing and it largely depends on the quality and condition of coal deposits, methods of breaking of coal beds and the technology of enrichment of mining product.

The processes of extraction of hard coal have been and are still accompanied by the generation of significant amounts of waste. In the past, due to limited possibilities of utilization, the larger part of waste was stored on the ground in a form of bings, dumps, dumping grounds and in mining waste landfills. Major differences in the manner of proceeding with wastes followed the introduction of payments for storage of waste in the 80 's of the previous century. Towards the end of the 90's of the last century 80 percent of waste produced by the hard coal mining was economically utilized. Currently around 5 percent of wastes generated by mining is stored.

\section{Coal mining in Poland}

Hard coal mines in Poland are located in Upper Silesia and the Dabrowskie Basin in the Upper Silesian Coal Basin (which includes the Upper Silesian Industrial Region and the Rybnik Coal Area) and also in Lower Silesia and the Lublin region - the Lublin Coal Basin. Places of occurrence of hard coal deposits are marked in black in the figure 1.

\footnotetext{
* Corresponding author: jpyssa@agh.edu.pl
} 


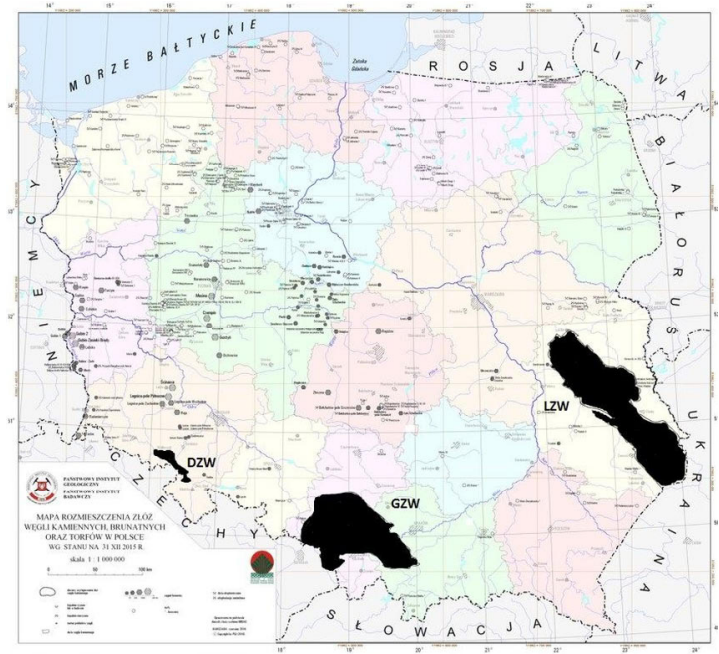

Fig. 1. Deposits of hard coal in Poland [1] DZW - the Lower Silesian Coal Basin, GZW - the Upper Silesian Coal Basin, LZW - the Lublin Coal Basin

According to the state as of the $31^{\text {st }}$ of December in Poland there are 155 deposits of hard coal. Recoverable resources altogether amount to 51960 million $\mathrm{Mg}$, exploited resources come to 19806 million $\mathrm{Mg}$, whereas not exploited resources total at 28177 million $\mathrm{Mg}$ [2].

The table 1 presents the condition of resources of hard coal in the year 2014 with the division by mining districts.

Table 1 Hard coal resources in 2014 [2]

\begin{tabular}{|c|c|c|c|c|c|c|}
\hline \multirow{2}{*}{$\begin{array}{c}\text { Deposit } \\
\text { resources }\end{array}$} & \multicolumn{5}{|c|}{ Geologically documented deposit } \\
\cline { 2 - 7 } & Exploited & $\begin{array}{c}\text { Not } \\
\text { exploited }\end{array}$ & $\begin{array}{c}\text { No longer } \\
\text { exploited }\end{array}$ & $\begin{array}{c}\text { Exploite } \\
\mathrm{d}\end{array}$ & $\begin{array}{c}\text { Not } \\
\text { exploited }\end{array}$ & $\begin{array}{c}\text { No } \\
\text { longer } \\
\text { exploited }\end{array}$ \\
\hline $\begin{array}{c}\text { Upper } \\
\text { Silesian } \\
\text { Coal } \\
\text { Basin }\end{array}$ & 50.0 & 44.0 & 42.0 & $19,024.0$ & $19,213.0$ & $3,735.0$ \\
\hline $\begin{array}{c}\text { Lublin } \\
\text { Coal } \\
\text { Basin }\end{array}$ & 1.0 & 10.0 & - & $9,565.0$ & 781.0 & $8,784.0$ \\
\hline $\begin{array}{c}\text { Lower } \\
\text { Silesian } \\
\text { Coal }\end{array}$ & - & 1.0 & 7.0 & - & 179.0 & 244.0 \\
Basin & & & & & & \\
\hline
\end{tabular}

The Upper Silesian Coal Basin is the main deposit of Poland. In this region all currently operating hard coal mines are located (apart from one). Up to $78.9 \%$ of documented recoverable resources of Polish coal mines are present in GZW - the Upper Silesian Coal Basin. In the Lublin Coal Basin there is one coal mine working - Bogdanka. In the Lower Silesian Coal Basin the exploitation of hard coal was finished in the year 2000 when the extraction in the Nowa Ruda coal mine was abandoned. The reason for discontinuation of 
the exploitation of deposits from that basin was difficult mining and geologic conditions which made the extraction unprofitable [3].

\section{Hard coal extraction in Poland}

Now there are 30 hard coal mines operating in Poland which extract altogether around 65 million $\mathrm{Mg}$ (the data for the year 2015). In relation to the year 2014 the extraction of hard coal decreased by 1.4 percent [3]. According to the data by the Ministry of Economy, the extraction of hard coal in the period of January to June 2016 amounted to 33598.8 thousand $\mathrm{Mg}$ and was higher than in the same period in 2015 by 330.2 thousand $\mathrm{Mg}$ [4]. The extraction of steam coal in the analyzed period of time in the year 2016 increased by 0.9 percent, while the coking coal extraction increased by $1.2 \%$. The detailed data is presented in the figure 2.

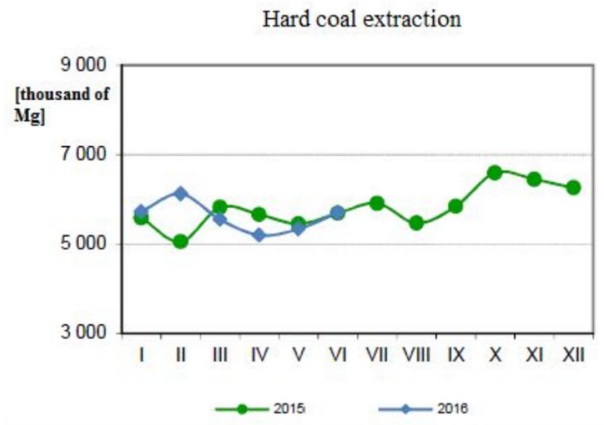

Fig. 2. Hard coal extraction in Poland in the years 2015 and 2016 [4]

\section{Extractive waste from hard coal mining}

The petrographic and chemical composition of waste from hard coal mining is varied and depends on geologic conditions of the exploited deposit. The waste derives from bottom and ceiling parts as well as overgrowth of coal beds which become the output during the deposit exploitation and then are separated from the coal in processes of enrichment.

The waste from hard coal mining is most often divided into mining waste and tailing waste because of the source of origin. The mining waste arises as a result of performing preparatory and enabling works. It is referred to as the gangue or waste rock [5]. It comprises around 6 percent of total mass of mining waste [6]. The tailing waste is generated on the ground and connected with the processes of hard coal enrichment - during sorting, rinsing and flotation of coal [7]. It comprises about $94 \%$ percent of total mass of hard coal mining waste [6].

\subsection{Petrographic, mineral and chemical composition}

The primary source of origin of the mining waste in Poland are building rocks along with coal decks of the Upper Carboniferous coal-bearing series of the Lower Silesian, Upper Silesian and Lublin coal basin. Siltstones, sandstones and conglomerates dominate in the Lower Silesian coal basin. In the Upper Silesian coal basin there are mudstones, siltstones and sandstones, while mudstones and siltstones prevail in the Lublin coal basin [7].

The mineral composition of hard coal mining waste is dependent on the share of particular carboniferous rocks in that waste. It is the loamy minerals such as: illite (28 to $82 \%)$ and kaolinite (9 to 65\%) - that dominate. Quartz (3-37\%), chlorite (less than 10 
percent) and pyrite also occur. Locally sulphides of other metals - galena $(\mathrm{Pb})$, sphalerite $(\mathrm{Zn})$, chalcopyrite $(\mathrm{Cu})$ and marcasite $(\mathrm{Fe})$ - can also be present. In the waste there are also potassium feldspars, plagioclases and muscovite $[7,8]$.

From a chemical point of view, the hard coal waste in Poland can be characterized with the presence of silica - the content of which ranges from 34.7 to 66.9 percent - and aluminium oxide $\left(\mathrm{Al}_{2} \mathrm{O}_{3}\right)$ - with the volume at about 21 percent. In the waste one can also find ferric oxides -0.9 to $12.9 \%$, potassium oxides -2 to 4.2 percent and calcium, sodium and titanium oxides in quantities of 1 to 2 percent. The data is presented in the table 2 .

Table 2. Elements occurring in waste from hard coal mining in Poland [author's own research based on $7,9,10]$

\begin{tabular}{|l|l|l|}
\hline Element & Lublin Coal Basin & Upper Silesian Coal Basin \\
\hline $\mathrm{As}, \mathrm{Sn}, \mathrm{Cd}, \mathrm{Co}, \mathrm{Cu}, \mathrm{Mo}, \mathrm{Ni}$, & less than $100 \mathrm{mg} / \mathrm{kg}$ & more than $100 \mathrm{mg} / \mathrm{kg}$ \\
\hline $\mathrm{Ba}$ & 270 to $762 \mathrm{mg} / \mathrm{kg}$ & locally even up to $3,000 \mathrm{mg} / \mathrm{kg}$ \\
\hline $\mathrm{Cr}$ & 132 & less than $100 \mathrm{mg} / \mathrm{kg}$ \\
\hline $\mathrm{Zn}$ & to $161 \mathrm{mg} / \mathrm{kg}$ & to $332 \mathrm{mg} / \mathrm{kg}$ \\
\hline $\mathrm{Mn}$ & - & $1,360 \mathrm{mg} / \mathrm{kg}$ \\
\hline $\mathrm{Hg}$ & less than $0.3 \mathrm{mg} / \mathrm{kg}$ & less than $0.3 \mathrm{mg} / \mathrm{kg}$ \\
\hline
\end{tabular}

In the hard coal mining waste slightly increased contents of radioactive isotopes of uranium, potassium and thorium occur $[7,11]$.

The volume of such elements as potassium, calcium, magnesium, nitrogen and phosphorus in the waste is very important in the process of reclamation with the use of waste, especially at the application of soilless method. The content of potassium is high enough [12], while other elements are present in insufficient quantities. The content of calcium is especially low [7].

The average content of carbon in the waste amounts to $9.4 \%$. The presence of carbon may involve a potential threat of thermal activity of waste at using it for engineering and reclamation works or during storage $[7,12]$.

\subsection{Amount of generated mining waste}

The hard coal mining is intrinsically linked to producing considerable quantities of waste. In the 80's of the previous century the extraction of $1 \mathrm{Mg}$ of coal was accompanied by 0.5 $\mathrm{Mg}$ of the extractive waste. Currently the number has decreased to $0.25-0.35 \mathrm{Mg}$ of waste which is a result of the application of modern technologies of coal extraction while taking into consideration the coal deposits which are more and more difficult to access [13]. In line with regulation of the Minister for the Environment as of the 29th of December 2014 concerning the catalogue of waste (Journal of Laws 2014, item 1923) [14], the waste generated as a result of the hard coal extraction was classified into the group 01- wastes resulting from exploration, mining, quarrying, physical and chemical treatment of minerals. And this group includes:

- 010102 - wastes from mineral non-metalliferous excavation,

- 010412 - tailings and other wastes from washing and cleaning of minerals other than those mentioned in 010407 and 010411 ,

- 010481 - wastes from floating enrichment of coal other than those mentioned in 010480 .

The figure 3 presents the data regarding the extraction of coal and the amount of extractive waste produced by the hard coal mining in the years 2010 to 2013 . 


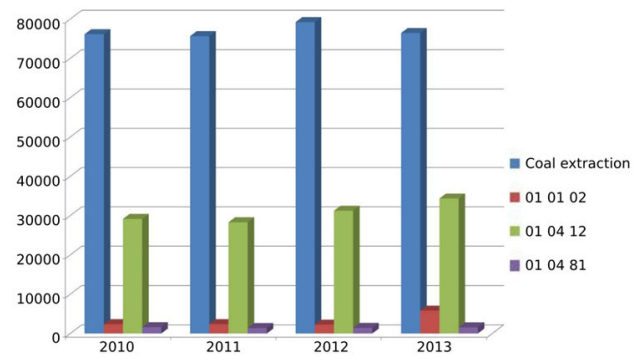

Fig. 3. Amount of generated extractive waste and coal extraction in the years 2010 to 2013 [author's own research based on [6]

In the analyzed period of time the biggest quantities of waste were produced in the group 010412 (tailings and other wastes from washing and cleaning of minerals other than those mentioned in 010407 and 010411 ) - from 82.3 percent of all waste generated in the year 2013 to 89.5 percent in the year 2012. The waste from the group 010102 (wastes from mineral non-metalliferous excavation) made up from $6.5 \%$ in the year 2012 to $14 \%$ in the year 2013, while the smallest amount of waste was produced in the group 010481 (wastes from floating enrichment of coal other than those mentioned in 0104 80) from $3.8 \%$ in the year 2013 to $4.8 \%$ in the year 2010 .

The table 3 presents ways of proceeding with the extractive waste.

Table 3. Amount of waste in the years 2010 - 2014 in division by subgroups and along with way of managing [author's own research based on [6]

\begin{tabular}{|c|c|c|c|c|c|}
\hline [thousand $\mathrm{Mg}$ ] & 2010 & 2011 & 2012 & 2013 & $2014^{1}$ \\
\hline \multicolumn{6}{|l|}{010102} \\
\hline Generated & $2,391.0$ & $2,385.8$ & $2,253.4$ & $5,827.3$ & $5,173.3$ \\
\hline Recovery & $2,304.2$ & $2,125.0$ & $1,624.1$ & $1,534.6$ & $1,159.9$ \\
\hline Neutralized & 82.7 & 167.2 & 509.3 & $3,821.9$ & $3,380.8$ \\
\hline Stored & 47.7 & 165.8 & 384.3 & $3,733.8$ & $3,133.0$ \\
\hline $\begin{array}{l}\text { Temporarily } \\
\text { warehoused }\end{array}$ & 4.1 & 93.6 & 120.0 & 470.8 & 369.5 \\
\hline \multicolumn{6}{|l|}{010412} \\
\hline Generated & $29,157.5$ & $28,306.2$ & $31,240.8$ & $34,361.1$ & $35,965.9$ \\
\hline Recovery & $26,618.1$ & $22,520.3$ & $26,332.9$ & $27,792.4$ & $14,570.2$ \\
\hline Neutralized & $2,206.1$ & $5,150.7$ & $4,768.9$ & $6,397.0$ & $5,603.8$ \\
\hline Stored & $1,001.6$ & $5,150.7$ & $4,768.9$ & $6,397.0$ & $5,603.8$ \\
\hline $\begin{array}{l}\text { Temporarily } \\
\text { warehoused }\end{array}$ & 333.3 & 635.2 & 139.0 & 171.7 & 65.1 \\
\hline \multicolumn{6}{|l|}{010481} \\
\hline Generated & $1,596.6$ & $1,395.2$ & $1,429.9$ & $1,571.0$ & $1,672.0$ \\
\hline Recovery & $1,421.8$ & $1,274.4$ & $1,385.7$ & $1,481.7$ & 911.4 \\
\hline Neutralized & 159.3 & 120.3 & 44.2 & 89.3 & 126.7 \\
\hline Stored & 46.7 & 120.3 & 44.2 & 89.3 & 126.7 \\
\hline $\begin{array}{l}\text { Temporarily } \\
\text { warehoused }\end{array}$ & 15.5 & 0.5 & 0 & 0 & 0 \\
\hline
\end{tabular}

${ }^{1}$ The data for the year 2014 relate to the waste managed by the producer on their own and cannot be compared to the preceding years due to changes in the legislation. 


\section{Current legal status}

The basic legislative act concerning the management of extractive waste is the Act as of $10^{\text {th }}$ of July 2008 on extractive waste (Journal of Laws No 138, item 865) [15] which transposes the provisions of the Directive 2006/21/WE into the national legislation.

The primary objective of the act is the prevention of waste generation in the extractive industry and reduction of the adverse impact of waste on people and the environment.

Those assumptions are supposed to be executed through the implementation of:

- rules of management of extractive wastes,

- rules of administration of facility for neutralizing extractive wastes,

- procedures related with obtaining permits and licenses connected with the extractive waste management,

- procedures related with the prevention of major functional failure in waste neutralization facilities of the category A.

Within the act a hierarchy of proceeding with extractive wastes was determined which obliges the producers to:

- use such manners of exploration, recognition, extraction, processing and storing which prevent the generation of extractive wastes and allow to keep their amount at the lowest possible level as well as reduce their negative influence on the environment and risk to human health and life, taking into consideration the best available techniques,

- submit extractive wastes to recovery and, if it is not possible due to technological reasons or not justified due to economic reasons, to submit it to neutralization processes in accordance with requirements for the environmental protection and the programme of extractive waste management, taking into consideration the best available techniques,

- transfer extractive wastes which cannot be submitted to recovery - for technological or economic reasons - to the nearest destinations in which it can be submitted to neutralization, taking into consideration the best available techniques and especially to facilities for the extractive waste neutralization.

The primary objective of the new act on extractive wastes - the Act of the $16^{\text {th }}$ of November 2012 (Journal of Laws no 0, item 1513) [16] - is the prevention of extractive waste generation in industrial extraction and reduction its negative influence on the environment and human health and life. According to the act, the stage of extractive waste management commences at the phase of planning of mining activities - so at the stage of design of the method of mineral extraction. Environmental aspects have become the crucial issue in the extractive waste management and they are the very key condition determining the selection of recovery process. Technological and economic issues ceased to be the priority.

The implementing acts are as follows:

- The regulation of the Minister for the Environment as of the $5^{\text {th }}$ of April 2011 on particular criteria for extractive waste neutralization facilities (Journal of Laws 2011 No 86 , item 477).

- The regulation of the Minister for the Environment as of the $15^{\text {th }}$ of July 2011 on criteria of classification of extractive waste as neutral waste (Journal of Laws 2011 No 175, item 1048).

- The regulation of the Minister for the Environment as of the $20^{\text {th }}$ of June 2013 on the characteristics of extractive waste (Journal of Laws 2013, item 759).

- The regulation of the Minister for the Environment as of the $29^{\text {th }}$ of May 2014 on conducting monitoring of extractive waste neutralization facilities (Journal of Laws 2014, item 875). 
- The regulation of the Minister for the Environment as of the $11^{\text {th }}$ of February 2015 on financial guarantee and its equivalent amount for extractive waste neutralization facility (Journal of Laws 2015, item 311).

\section{Directions of use of waste of hard coal mining}

From the analysis of available data it follows that around 93 percent of waste produced during the exploitation and processing of raw minerals is economically used. Out of this quantity merely 30 percent is used industrially and nearly $70 \%$ is applied for leveling of grounds, engineering works and so-called 'earth structures' and 'landscape forms' $[17,18]$.

To the primary directions of the economic use of waste of hard coal mining one should include $[16,19]$ :

- reduction at the 'source' - at the stage of design and through the optimization of technologies applied for drilling the deposit,

- recovery - in a coal mine under the ground and on the ground,

- neutralization through storage.

One of elementary ways of limiting the generation of waste which arises during the hard coal extraction is the adjustment of machines and supports to smaller coal decks. Carbon and tailing waste is used in the coal mine for filling mine workings as a component of hydraulic and pneumatic backfill [11]. The addition of 50 percent of gangue to the hydraulic backfill influences the increase of its compressibility and flow resistance and improves the water yield and sedimentation rate [7, 20]. Ashes from the coal combustion are also added to the hydraulic backfill [11, 21-23]. The dominating technology of hydraulic backfill is based on the backfilling sand with the addition of other materials ground fossil stone of particle size of more than $0,1 \mathrm{~mm}$ most frequently [24]. Very finegrained waste coming from the flotation of coal along with binding material can also be added. The waste is used in mining technologies for sealing goafs (abandoned workings), preparing paste backfill, eliminating empties in the rock mass, producing backfilling corks and belts and in the fire safety practice $[7,11,23]$.

In the Polish hard coal mining the paste backfill was used for the very first time in the "Jastrzębie" coal mine during the exploitation of a deck number 510/1-2. It was applied because of the geological structure and physicochemical properties of the deck - which was very low coal firmness. The content of the used paste backfill included: 40 to 50 percent of fly ashes, 50 to $60 \%$ of waste from coal floatation and 2 to 3 percent of cement [24]. The method allows to use salty mine waters as the mixing (batch) water [25].

The common practice is using the extractive waste for reclamation and leveling of land, elimination of workings after the exploitation of raw materials [7, 13, 17]. In order to achieve that the waste with codes 010212 and 010102 are the most frequently used [18]. Filling - in of the area is done up to the heights of adjacent non-transformed lands. In order to be used in this way the waste must meet requirements in the range of chemical composition as defined in the regulation. To be able to use the extractive waste in such way it is necessary to limit thermal phenomena connected with processes of the oxidation of carbon substance and pyrite. For that purpose one uses the waste deriving from the combustion of coal (slag, fly ashes, ash-slag mixtures, waste from desulphuring exhaust gases) which serve as screens and also reduce leaching of waste as well as limit the migration of contamination to groundwater [7]. One also uses fine-grained waste coming from floatation which disintegrate easily due to the presence of argillaceous rocks and foster the concentration of waste.

The coarse-grained and extractive waste from the processes of coal enrichment have been applied as the aggregate in road construction and engineering works. It is first of all 
used in earthworks by road investments for forming embankments and slopes $[11,13,18$, 26].

Mining waste - because of the high content of argillaceous rocks - has been used in the production of ceramic building materials. In the process of firing ceramics mudstone and sandstones present in the waste play a role in weakening the ceramic mass [7]. However, not all sorts of waste can be used in this way. The limitation is the occurrence of pyrite and siderite in the waste which are components responsible for obtaining products of lowered quality.

Waste containing large amounts of block shale is used in the cement industry as a clay and silicon-bearing material in the production of portland cement [7].

The modern technology is sintering coal mud with the addition of sewage sludge the result of which is the production of high-quality aggregate [13, 19].

Coal slime - these are by-products resulting from rinsing coal dusts which were previously deposited in tailing ponds and now are used as low-energy fuel [13]. They are incinerated either immediately in power plants in boilers with fluidized bed or burnt together with the coal dust $[7,27]$. The modern technology applied by Haldex SA company is the manufacturing of granulate on the basis of coal mud (from the current production and collected from settlement ponds) and calcium oxide [13]. That product can be characterized with lower moisture content and the calcium oxide included in it plays a role of sorbent material binding sulphur monoxides. There is also the generation of granulate based on grinded bottom ash. The granulate can be characterized with good energetic properties and resistance against the action of external factors at small portions of adhesive [28].

Another coal mud-based product made by Haldex company is BioCarbohumus. The addition here is- apart from the coal mud- the sewage sludge. The high content of nitrogen and phosphorus in the sewage sludge contribute to making BioCarbohumus rich in nutrients which are essential for the development of plants $[13,29]$. The product has been applied in the reclamation of industrially contaminated lands and waste landfills [7, 13].

\section{Impact on environment}

The waste generated as a result of exploration and processing of coal affects all components of the environment. During movement, storing and technical reclamation the waste undergoes the action of external factors. Under the influence of sun and wind the surface of waste dries which causes enhanced emission of dusts to the atmosphere. The access of air makes the coal and mineral substance oxidize which results in the emission of $\mathrm{CO}, \mathrm{CO}_{2}$, $\mathrm{NO}_{\mathrm{x}}, \mathrm{SO}_{2}$, polycyclic aromatic hydrocarbons $(\mathrm{PAH})$ and $\mathrm{C}_{\mathrm{x}} \mathrm{H}_{\mathrm{y}}$. As a result of the oxidation of pyrite located in stored coal waste a strong exothermic reaction takes place which may lead to self-heating of waste and generating the critical temperature of coal ignition. This leads often to the spontaneous combustion of waste [7].

An extremely important issue is the impact of stored carbon waste onto the hydrosphere. The most important factor deciding about the scale of effect of the waste on the aquatic environment is the sort and content of soluble components in the fresh waste. It concerns especially the quantity of chlorides and primary sulphates. Soluble components, which have come into existence as an outcome of physicochemical processes (weathering) occurring after waste disposal, are of high significance. This mainly concerns the decomposition of reactive sulphides (first of all iron) as a result of which sulphates and sulphuric acid arise. Clay minerals - calcium carbonate and magnesium carbonate in particular - have neutralizing effect [7]. Another very important factor is the availability of leaching water. Both the scale and range of transportation of contaminants away from the structure of waste landfill depends on the geological structure of bedrock and 
hydrogeological conditions of all area. Increased amounts of sulphates, chlorides and sodium were found in aqueous extracts.

\section{Summary}

Hard coal mining is one of biggest producers of waste in Poland. The amount of generated extractive waste is strictly related to: volume of coal production, currently exploited part of deposit, conducted exploitation system and applied technologies of enrichment in a processing plant. The implementation of rules for managing the extractive waste and search for savings through its economic use (gaining profits and/or avoiding losses) can undoubtedly bring measurable benefits. Unfortunately, a considerable part of extractive waste is still managed by storing on bings. It results in the increase of hard coal production costs and causes permanent adverse changes in the natural environment. As it stems from the data placed in this article a significant part of extractive waste, after its proper processing, can be used in an economic manner.

The work is financed within the frames of statutory research no 11.11.210.213 at the Faculty of Energy and Fuels.

\section{References}

1. http://geoportal.pgi.gov.pl/css/surowce/images/2015/mapy/large/large_8.jpg

2. Environment 2015 (Central Statistical Office of Poland, Warsaw, 14.12.2015). http://stat.gov.pl/en/topics/environment-energy/environment/environment$2015,1,7 . \mathrm{html}$

3. The balance of mineral resources deposit in Poland as of 31.12 .2015 (PIG-PIB, Warszawa, 2016) https://www.pgi.gov.pl

4. Ministry of Energy, Information on the Functioning of coal mining in June and in the period January-June $2016 \quad$ (Warszawa, 2016) http://www.me.gov.pl/Gornictwo/Realizacja+Programu+dzialalnosci+gornictwa+wegl $\mathrm{a}+$ kamiennego $+\mathrm{w}+$ Polsce

5. W. Kotowski, Utylizacja i gospodarka odpadami (Wyd. WSEiA, Bytom, 2006)

6. Central Statistical Office of Poland, 2016 http://swaid.stat.gov.pl

7. Z. Mirkowski, J. Badera, 010412 Rekultywacje wyrobisk z wykorzystaniem odpadów z wydobycia węgla kamiennego $w$ województwie lubelskim (Lublin, 2015)

8. Z. Bzowski, Wiadomości Górnicze, 64, 2, 93-98 (2013) http://yadda.icm.edu.pl/yadda/element/bwmeta1.element.baztech-article-AGHL-00050041?q=3fb1 ccd2-8ebd-45ed-8c89-fc6d0492f4e9\$4\&qt=IN_PAGE

9. B. Klojzy-Karczmarczyk, J. Mazurek, Zeszyty Naukowe IGSMiE PAN, 90, 67-78 (2015); http://yadda.icm.edu.pl/yadda/element/bwmeta1.element.baztech-7b8b90974a20-48f4-832a-88a564b3f857

10. A. Strugała, D. Makowska, K. Bytnar, T. Rozwadowska, Polityk Energetyczna Energy Policy Journal 17, 4, 77-88 (2014); https://www.minpan.krakow.pl/Wydawnictwa/PE174/(z4)-06-strugala-makowska-i-in.pdf

11. J. Pyssa, J. Rokita, Przegląd Górniczy 68/12, 132-138 (2012) http://yadda.icm.edu.pl/yadda/element/bwmeta1.element.baztech-e36b801d-f368442d-8733-1763ec5f83bf

12. K. Bojarska, Z. Bzowski, Górnictwo i Geologia, 7, 2, 101-113 (2012) https://www.polsl.pl/Wydzialy/RG/Wydawnictwa/Documents/kwartal/7_2_8.pdf

13. M. Kugiel, R. Piekło, Górnictwo i Geologia, 7, 1, 133-145 (2012) https://www.polsl.pl/Wydzialy/RG/Wydawnictwa/Documents/kwartal/7_1_12.pdf 
14. Regulation of the Minister for the Environment as of the $9^{\text {th }}$ of December 2014 concerning the catalogue of waste (Journal of Laws 2014, item 1923)

15. Act as of $10^{\text {th }}$ of July 2008 on extractive waste (Journal of Laws No 138, item 865)

16. Act of the $16^{\text {th }}$ of November 2012 (Journal of Laws no 0, item 1513)

17. S. Góralczyk, E. Żbikowska, Prace Naukowy Instytutu Górnictwa Politechniki Wrocławskiej. Studia i Materiały, 41, 93-104 (2012). http://yadda.icm.edu.pl/baztech/element/bwmeta1.element.baztech-article-BPW60025-0009

18. J. Kamyk, A. Kot-Niewiadomska, Inżynieria Środowiska 38, 23-31 (2015) http://yadda.icm.edu.pl/yadda/element/bwmeta1.element.baztech-a4ea3150-b93645a8-b79d-3b48f444ea1a

19. S. Góralczyk, I. Baic, Polityka Energetyczna - Energy Policy Journal, 12(2/2), 145157 (2009) http://meeri.pl/se/pelne_teksty23/k23z_pe/k23_goralczyk_baic_z.pdf

20. F. Plewa, Z. Mysłek, Zagospodarowanie odpadów przemysłowych $w \bar{p}$ odziemnych technologiach górniczych. (Politechnika Śląska, 2001)

21. J. Pyssa, Gospodarka Surowcami Mineralnymi - Mineral Resources Management. 21/3, 83-93 (2005) http://www.meeri.eu/Wydawnictwa/GSM213/pyssa.pdf

22. F. Plewa, M. Popczyk, P. Piontek, Polityka Energetyczna - Energy Policy Journal 12(2/2), 485- $495 \quad$ (2009). 4 http://www.minpan.krakow.pl/se/pelne_teksty23/k23z_pe/k23_plewa_popczyk_piontek_z.pdf

23. J. Pyssa, E3S Web of Conferences, 10, 00077 http://dx.doi.org/10.1051/e3sconf/20161000077

24. F. Plewa, M. Popczyk, P. Pierzyna, Polityka Energetyczna - Energy Policy Journal 16(4), 257-270

http://yadda.icm.edu.pl/baztech/element/bwmeta1.element.baztech-dc62e6fd-04c94341-8b55-27d6b510800c/c/plewa.pdf

25. J. Palarski, F. Plewa, Z. Małysek, Odzysk i unieszkodliwianie odpadów w górnictwie podziemnym Wyd. Politechniki Opolskiej (Gliwice, 2012)

26. J. Pyssa, Przegląd Górniczy, 66/5, 38-44 http://yadda.icm.edu.pl/baztech/element/bwmeta1.element.baztech-article-BGPK2859-1183

27. I. Jelonek, Z. Mirkowski, International Journal of Coal Geology, 139, 228-236 (2015) http://dx.doi.org/10.1016/j.coal.2015.02.005

28. A. Szymkiewicz, J.J.Hycnar, A. Fraś, R. Przystaś, T. Józefik, I. Baic, Journal of the $\begin{array}{llllll}\text { Polish Mineral Engineering Society, 1, } & 19-30 \quad \text { (2012) }\end{array}$ http://www.potopk.republika.pl/Full_text/im_29_r3_szymkiewicz_hycnar.pdf

29. J. Pyssa, Logistyka, $\quad \overline{4}, \quad 9633-\overline{9} 642$ http://yadda.icm.edu.pl/yadda/element/bwmeta1.element.baztech-c0765b1c-2f45-4afc$9 \mathrm{cc} 0-743542 \mathrm{ece} 8 \mathrm{a} 9$ 